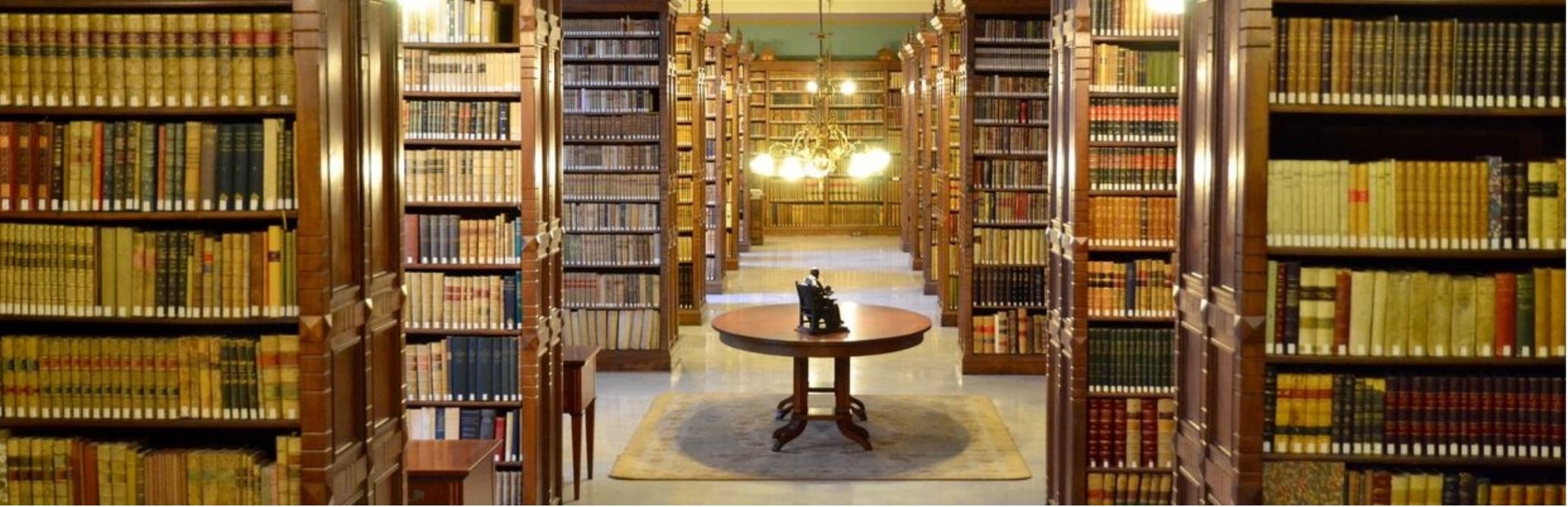

\title{
Editorial Volume 7, Issue 4
}

$\begin{aligned} \text { Authors: } & \text { Stephan Seiler } \\ \text { Submitted: } & \text { 7. September } 2020 \\ \text { Published: } & 8 \text {. September } 2020 \\ \text { Volume: } & 7 \\ \text { Issue: } & 4 \\ \text { Affiliation: } & \text { JOSHA } \\ \text { Languages: } & \text { English } \\ \text { Keywords: } & \text { Editorial, Josha Journal, July - August } 2020 \\ \text { Categories: } & \text { News and Views } \\ \text { DOI: } & 10.17160 / \text { josha.7.4.709 }\end{aligned}$

Abstract:

Dear JOSHA readers, once again we find ourselves saying goodbye and closing another wonderful issue! This bi-monthly issue is full of wonderful articles, including more of the candidates and possible winners of the 2020 Demetrios Award. In addition, we would like to remember you that you can support us with a small donation. On the other hand, don't miss the opportunity to visit our social media and get to know us from the Instagram gallery and the Facebook wall. Remember that you can comment on the articles and also provide your star ranking.

\section{JOSHA Jouna ofseserees Humanities and Arts




\section{EDITORIAL}

\section{VOLUME 7, ISSUE 4}

Dear JOSHA readers, once again we find ourselves saying goodbye and closing another wonderful issue! This bi-monthly issue is full of wonderful articles, including more of the candidates and possible winners of the 2020 Demetrios Award. In addition, we would like to remember you that you can support us with a small donation. On the other hand, don't miss the opportunity to visit our social media and get to know us from the Instagram gallery and the Facebook wall. Remember that you can comment on the articles and also provide your star ranking.

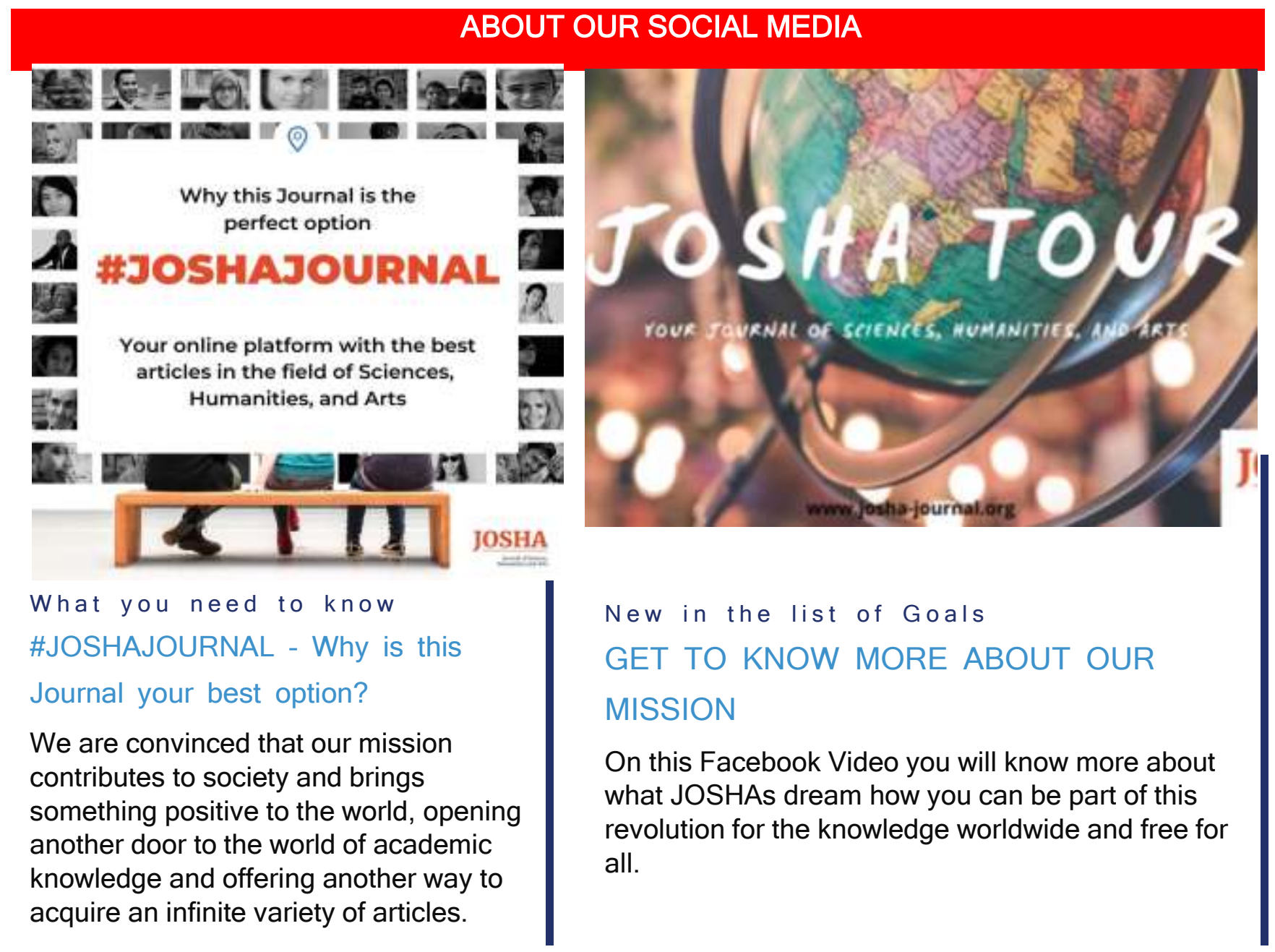

\section{Demetrios Prizes}

This year 2020, Josha-Journal together with the International Academy of Sciences, Humanities and Arts IASHA e.V. will again award Demetrios Prizes to young scientists. Several applications have already been received in the Bachelor, Master and PHD fields and the deadline was by the end of August. The winners will 
now be selected in September and announced in October. All submitted papers will be published in our journal. We are curious to see what spectrum the contributions will cover this year.

\section{Social Media Activities}

The Journal of Sciences, Humanities and Arts has intensified its activities on the social media channels YouTube, Facebook and Instagram. On Instagram have an increase of $25 \%$ in followers since the beginning of the year, on YouTube there are informational videos about the Journal and former Demetrios award winners report about their experiences. On Facebook and Instagram, we introduce our team. On Facebook you can also find the videos about submission and sign up to Josha-Journal.

\section{Your Donation for Josha-Journal}

Once again, we celebrate the mission of JOSHA to offer its library services. As a non-profit organization we have been able to provide scholarships to significantly support the careers of many students, artists, and young scientists from all around the world. Our open-access journal lays out a forum where they can present their achievements. There, you can value their presentations and follow-up on the impact of your donation. Today we are announcing a new button on our website through which you can support us. With your donation you set a sign of philanthropy and help to continue our mission to support the future careers of young gifted people.

Now we hope you enjoy reading the journal. We are looking forward to the announcement of the winners in October and to many exciting further contributions.

Stephan Seiler on behalf of the JOSHA Team

Table of Content: http://www.josha-journal.org/en/issues

Leah Biebert, "Sie sitzen daheim und denken sich Geschichten aus". The Representation of Authorship in Daniel Kehlmann's Literary Works

Christopher Winterhalder, Sport in der Ganztagsschule - Sports in full day Schools

Franziska Buttgereit, Poverty is the Mother of Health

Frank Wertheimer, Nochmal: Rückforderung von Berufungs-Leistungsbezügen wegen vorzeitigem Wechsel der Hochschule - Once again: Reclaim of appellate benefits

Gerhard Steinmann, Silke Masullo, JOSHA SCHOLARSHIP FUND to support young students, artists, scientists from all around the world

Eugen Carasevici, Pandemic SARS CoV -2 - a Romanian perspective. The perception of a septuagenarian doctor

Gisela Pattarone, Enfermedades Crónicas No Transmisibles en Argentina - Chronic Non-Communicable Diseases in Argentina

Bujar Q. Bajçinovci, Mimoza M. Dugolli, COVID-19 Impacts on High Education: Virtual Learning

Challenges on University of Prishtina

Chiara Giardi, Mapmaking and Storytelling

María Fernanda Sandoval, Editorial Volume 7, Issue 3

Madelay Coromoto Escobar Uztariz, Exposición de la muerte como satisfacción anónima de algunos

Hombres - Death as an anonymous Satisfaction of some Men 